\title{
Retention of Organic Matter Contained in Industrial Phosphoric Acid Solution by Raw Tunisian Clays: Kinetic Equilibrium Study
}

\author{
Wiem Hamza, ${ }^{1}$ Chaker Chtara, ${ }^{2}$ and Mourad Benzina ${ }^{1}$ \\ ${ }^{1}$ Laboratory of Water-Energy-Environment (LR3E), National School of Engineers of Sfax, University of Sfax, BP W, 3038 Sfax, Tunisia \\ ${ }^{2}$ Tunisian Chemical Group, 6000 Gabes, Tunisia
}

Correspondence should be addressed to Wiem Hamza; hamzawiem@gmail.com

Received 27 May 2013; Accepted 16 September 2013

Academic Editor: Yuangen Yang

Copyright (c) 2013 Wiem Hamza et al. This is an open access article distributed under the Creative Commons Attribution License, which permits unrestricted use, distribution, and reproduction in any medium, provided the original work is properly cited.

\begin{abstract}
Purification of industrial phosphoric acid $\left(\mathrm{H}_{3} \mathrm{PO}_{4}\right)$ is considered a major problem and several methods have been evaluated. In this study, two different types of clay, raw bentonite clay (RBC) and raw grey clay (RGC), were used for removal of SOM contained in $\mathrm{H}_{3} \mathrm{PO}_{4}$ at low $\mathrm{pH}$. The used samples were characterized by X-ray diffraction, chemical analysis, and specific surface area and MET was also realized. The ability of clay samples to remove S.O.M from aqueous solutions of industrial phosphoric acid has been studied at different operating conditions: temperature, agitation speed, contacting time, and so on. The results indicated that adsorption is an exothermic process for lead S.O.M removal. The equilibrium adsorption data were analysed using the Langmuir and Freundlich isotherms. The results showed that the equilibrium adsorption capacities for the two adsorbents followed best the Langmuir model. Thermodynamic parameters showed that the adsorption process was spontaneous and exothermic.
\end{abstract}

\section{Introduction}

The phosphoric acid is manufactured using different processes; the most commonly used area is thermal and wetprocess $[1,2]$. Phosphoric acid produced by this process contains a variety of impurities, which vary according to the origin of the minerals. Tunisian phosphoric acid $\left(54 \% \mathrm{P}_{2} \mathrm{O}_{5}\right)$ contains about 10 molar impurities per 100 molar $\mathrm{H}_{3} \mathrm{PO}_{4}$ [3] .

The crude acid produced by the wet process is heavily entrained with both mineral (arsenic, cadmium, fluoride, sulfate, copper, and so on) and organic impurities (di-n-butyl phthalate, humic acid, and fulvic acid) [4]. Depending on the industrial phosphoric acid origin and quality, organic matter content is generally between 300 and 700 ppm [5]; these organic impurities affect the acid grade.

Many of these impurities, particularly the solid impurities, are removed from the acid, whatever their uses are, by techniques such as clarification. The presence of these impurities affects the quantity and the quality of the product [6]. For this reason, about $95 \%$ of the acid produced by the wet process is directly used as fertilisers and excluded from the use in nonfertiliser applications [7]. Organic matter can be found both as colloidal suspension and in soluble form [8]. With the aging of $\mathrm{H}_{3} \mathrm{PO}_{4}$, the colloidal organics coagulate with the precipitating gypsum, while the soluble organics remain in solution [9]. A great number of research works have been reported in the literature concerning the purification of phosphoric acid and particularly the elimination of the heavy metal cations [10]. However, only few studies are dealing with the removal of organic compound. Most of the adopted processes to achieve this task are mainly based on either liquid-liquid extraction or adsorption on suitably chosen solid supports [11].

Many kinds of adsorbents have been developed for the removal of humic substance (HS) from water. Previous research has suggested that activated carbon, as well as resins, can be reasonably used in order to remove HS from water [12]. Recently the usage of natural mineral sorbents for wastewater treatment is increasing because of their abundance and low price [13] like bentonite clay mineral. Consequently, the purpose of this work is to study the feasibility of OM present in Tunisian wet phosphoric acid elimination onto two different types of Tunisian clays from two different regions. An equilibrium adsorption isotherms' analysis to 


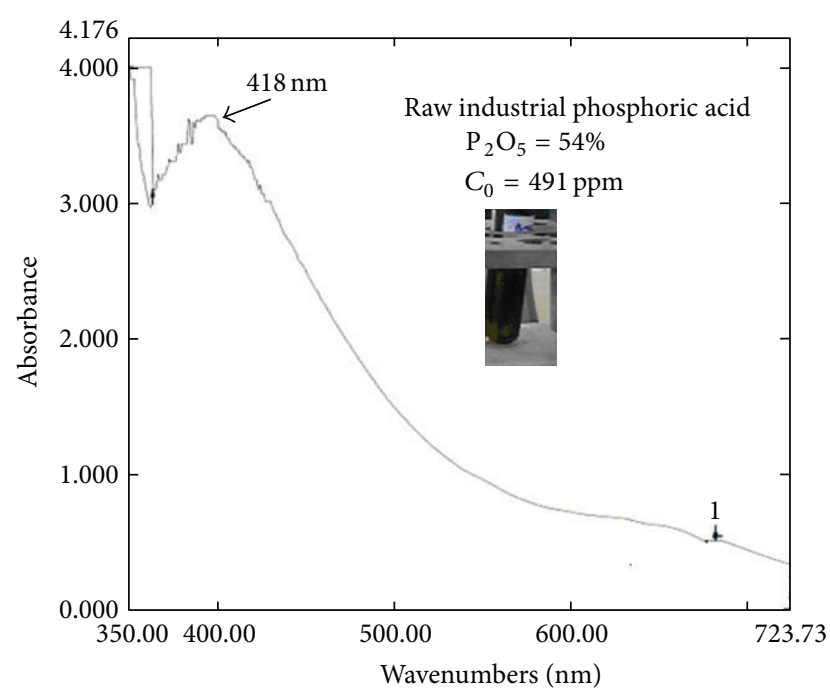

FIGURE 1: Spectrum of wavelength of $54 \%$ industrial phosphoric acid solution.

obtain the Langmuir and Freundlich constants was realized. A fully Kinetic investigation is also undertaken. Results are compared with those obtained with activated carbon.

\section{Materials and Experimental Procedures}

2.1. Industrial Phosphoric Acid. Phosphoric acid used in this study is produced by Tunisian Phosphate Mines-GCT complex located in Gabes, South of Tunisia. Qualitative and quantitative analyses of phosphoric acid have already been performed in previous studies [5]. The wet phosphoric acid which we treated initially contains an equal amount to $54.65 \% \mathrm{P}_{2} \mathrm{O}_{5}$ and a quantity of organic matter equal to $491 \mathrm{mg} / \mathrm{L} .82 \%$ by weight of organic matter consists of humic substance (Figure 1). Figure 2 showed the spectrum scanning wavelength of $54 \%$ industrial phosphoric acid solution which confirms that the OM concentration in the clear supernatant at different time intervals can be determined spectrophotometrically at $418 \mathrm{~nm}$ [14-16]. The viscosity of phosphoric acid was determined in the temperature range of $16-50^{\circ} \mathrm{C}$. The density, viscosity, and the chemical composition of $\mathrm{H}_{3} \mathrm{PO}_{4}$ were measured with results shown in Table 1.

2.2. Phosphoric Acid Used as Reference. The phosphoric acid used as reference was obtained by continuous stirring at room temperature of phosphoric acid with activated carbon of less than $0.15 \mathrm{~mm}$ in size during a whole day. The acid obtained was filtered on paper filter and the above procedure was repeated for five days until the phosphoric acid was OM-free and used as a blank in the UV spectrophotometric analysis $[15,16]$.

2.3. Bentonite and Gray Clay. In this study, two raw materials were used: bentonite and gray clay which were sampled in Djebel Hamma in Gabes area (Southeast of Tunisia)
TABLE 1: Physical and chemical characteristics of 54\% industrial phosphoric acid solution.

\begin{tabular}{lc}
\hline Material & $\mathrm{H}_{3} \mathrm{PO}_{4}$ \\
\hline Organic matter $(\mathrm{ppm})$ & 491 \\
$\mathrm{P}_{2} \mathrm{O}_{5}$ percentage $(\%)$ & 54.26 \\
$\mathrm{Ph}$ & $\approx 1$ \\
Density & 1.6 \\
$\mathrm{Al}(\mathrm{mg} / \mathrm{L})$ & 10470 \\
$\mathrm{Ca}(\mathrm{mg} / \mathrm{L})$ & 4200 \\
$\mathrm{Fe}(\mathrm{mg} / \mathrm{L})$ & 14600 \\
$\mathrm{Cd}(\mathrm{mg} / \mathrm{L})$ & 24.315 \\
$\mathrm{Cr}(\mathrm{mg} / \mathrm{L})$ & 380.2 \\
$\mathrm{Viscosity}(\mathrm{cPo})$ & 6.34 \\
\hline
\end{tabular}

and Djebel Cherahile, Kairouan-Tunisia (Center of Tunisia), respectively.

2.4. Characterisation Methods. To determine the various chemical species, constituting the clay material, normative mineral composition was calculated from the quantitative chemical analysis obtained by X-ray powder diffractometer (Rigaku D-Max 2200 model). For the loss on the ignition (LOI) determination, the raw clay material was calcined at $1000^{\circ} \mathrm{C}$.

To identify the mineralogical composition of the material and the changes of interlayer spacing of the prepared samples, a Philips analytical X-ray diffractometer was used employing filtered $\mathrm{Cu}$ radiation generated at $40 \mathrm{kV}$ with a scan rate of $1^{\circ} / \mathrm{min}$ at room temperature. Bragg's law, defined as $n \lambda=$ $2 d \sin \theta$, was used to compute the crystallographic spacing (d) for the examined clays (where $\lambda$ corresponds to the wavelength of the $\mathrm{X}$-ray radiation used for the diffraction experiment and $\theta$ is the measured diffraction angle).

$\mathrm{X}$-ray diffractograms were obtained on oriented samples. To prepare the oriented films, the clay material was dispersed in distilled water, and after sedimentation; the fractions with particle size smaller than $2 \mu \mathrm{m}$ were recuperated and deposited on glass slides. Three blades were analyzed: the first was normal, the second was heated at $550^{\circ} \mathrm{C}$ during $4 \mathrm{~h}$, and the third was exposed to the vapour of ethylene glycol during $24 \mathrm{~h}$ [17].

The density of the clay mineral was measured by pycnometry in order to determine the real density $\rho S$; the fluid chosen to penetrate in porous space was water, whereas, for the apparent density, mercury was chosen since it does not penetrate in the porous network [18]; one can also cover the sample by a film with wax and use water like pycnometric fluid. $\mathrm{N}_{2}$ adsorption isotherms were recorded on a Micromeritics ASAP 2010 gas analyzer. Surface areas were measured by the BET method and the pore size distributions and pore volume were measured by the $\mathrm{BJH}$ method. The samples that have particle sizes lower than $100 \mu \mathrm{m}$ were degassed as a preliminary to $60^{\circ} \mathrm{C}$ during 72 hours, and then the cell was plunged in a liquid nitrogen balloon. For transmission electron microscopy, micrographs are recorded on an apparatus JEOL JEM-100CXII operating at $200 \mathrm{KeV}$. 


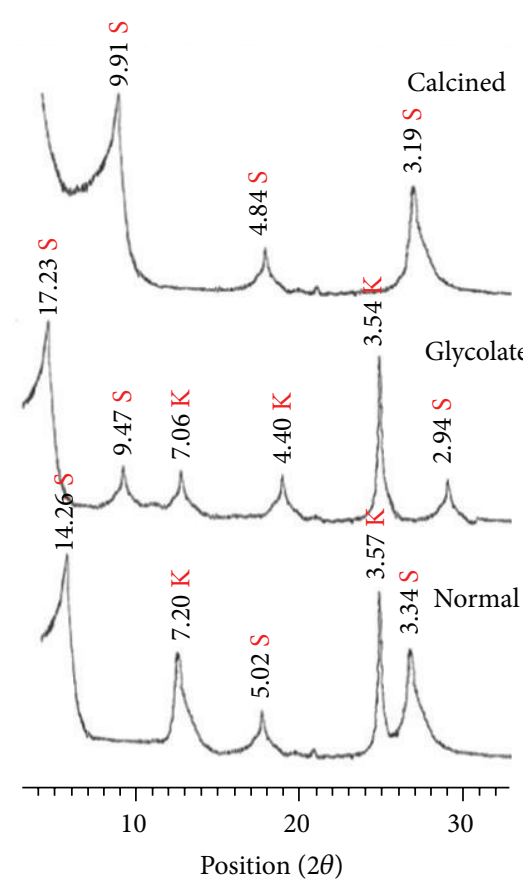

(a)

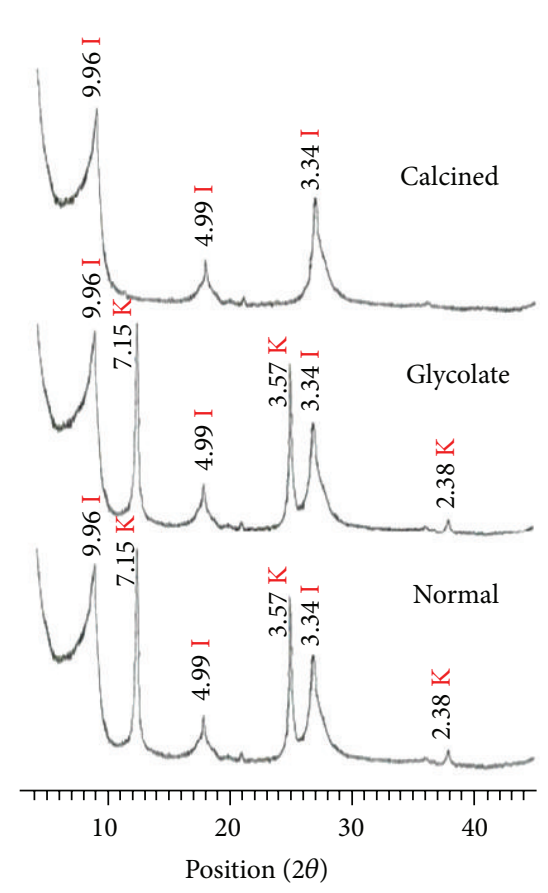

(b)

FIGURE 2: X-ray diffraction patterns of (a) RBC and (b) RGC.

To prepare the sample, a few milligrams of clay mineral powder are mixed in a beem capsule with agar 100 embedding resin. After polymerization at $60^{\circ} \mathrm{C}$ overnight, the blocks are cut using a microtome equipped with a diamond knife. The ultrathin slices, $\sim 50 \mathrm{~nm}$, are recovered on copper grids and examined.

2.5. Organic Matter Removal Test (Experimental Procedure). The industrial phosphoric acid solution used was a $54 \% \mathrm{P}_{2} \mathrm{O}_{5}$ (about $9 \mathrm{M} \mathrm{H}_{3} \mathrm{PO}_{4}$ ) solution containing an initial concentration of organic matter $(\mathrm{OM})$ equalizing with $491 \mathrm{ppm}$. The removal of OM was carried out in the following manner: a known amount of used adsorbents was placed in Erlenmeyer flasks of $250 \mathrm{~mL}$ capacity in contact with $50 \mathrm{~mL}$ of industrial phosphoric acid solutions at a certain temperature $\left(35-55^{\circ} \mathrm{C}\right)$ under variable agitation speed (200-600 rpm) at very acidic $\mathrm{pH}$ value. After contact desired time and at equilibrium, the dispersions were filtered, and the OM concentration was determined by spectrophotometry (UV-visible spectrophotometer 1650, SHIMADZU) at a wavelength of $418 \mathrm{~nm}$ (Figure 2).

The amount of OM adsorbed was calculated by using the following equation:

$$
q_{e}=\frac{\left(C_{i}-C_{f}\right)}{M} \times V
$$

where $q_{e}$ is the amount of OM adsorbed on the clay $\left(\mathrm{mgg}^{-1}\right)$, $C_{i}$ is the initial OM concentration in solution $\left(\mathrm{mg} \mathrm{L}^{-1}\right), C_{f}$ is the final $\mathrm{OM}$ concentration in solution $\left(\mathrm{mg} \mathrm{L}^{-1}\right), V$ is the volume (L), and $M$ is the amount of clay (g).
The kinetic study was carried out on the same experimental setup by varying one parameter and keeping the others constant.

\section{Results and Discussion}

3.1. Characterisation of the Adsorbent. The RBC sample contains smectite (bentonite) as the major clay mineral associated with illite and kaolinite; this clay mineral was characterized by the $\left(\begin{array}{lll}0 & 0 & 1\end{array}\right)$ basal reflections at $14.7 \AA, 10.04$ and $7.17 \AA$ [17] on rock powders (Figure 2(a)). The RGC sample contains illite as major clay minerals (Figure 2(b)). The diffraction characteristics of quartz and calcite appear clearly on XRD patterns of RGC.

TEM micrographs (Figures 3(a) and 3(b)) of the raw used clay show a (001) reflexion corresponding to 1.46 and $0.95 \mathrm{~nm}$, respectively. This result is in agreement with the value obtained by XRD. So the TEM observation of the two samples RBC and RGC supports RX results found previously.

The chemical analysis showed that the main constituents of raw clay materials (RBC and RGC) are silica, alumina, iron, calcium (RGC), and magnesium (RBC) oxides (Table 2). The absence of correlation between $\mathrm{SiO}_{2}$ and $\mathrm{Al}_{2} \mathrm{O}_{3}$ contents indicates that the excess of $\mathrm{SiO}_{2}$ is due to the presence of quartz, as shown by XRD. RBC sample has higher content of $\mathrm{MgO}(3 \%)$ than the RGC sample (1.2\%) (Table 2); such difference is explained by the occurrence of smectite amounts.

Textural analysis of the RBC and RGC adsorbents is given in Table 3. By comparison with RGC sample, it is clear that the RBC sample has a higher specific surface area, total pore volume, internal porosity and pore size. Moreover, RBC is more porous than RGC. 
TABLE 2: Chemical characteristics of raw clays (in mass \%).

\begin{tabular}{lcccccccccc}
\hline Oxides $\%$ & $\mathrm{SiO}_{2}$ & $\mathrm{Al}_{2} \mathrm{O}_{3}$ & $\mathrm{Fe}_{2} \mathrm{O}_{3}$ & $\mathrm{~K}_{2} \mathrm{O}$ & $\mathrm{MgO}$ & $\mathrm{Na}_{2} \mathrm{O}$ & $\mathrm{MnO}$ & $\mathrm{ZnO}$ & $\mathrm{CaCO}_{3}$ & $\mathrm{LOI}$ \\
\hline RGC & 43.38 & 16.82 & 8.67 & 0.86 & 3.46 & 0.53 & 0.05 & 0.12 & 7.10 & 8.56 \\
$\mathrm{RBC}$ & 50.91 & 16.59 & 10.56 & 0.96 & 1.2 & 1.85 & 0.04 & 0.19 & 3.02 & 11.2 \\
\hline
\end{tabular}

LOI: loss ignitions; RBC: raw bentonite clay; RGC: raw gray clay.

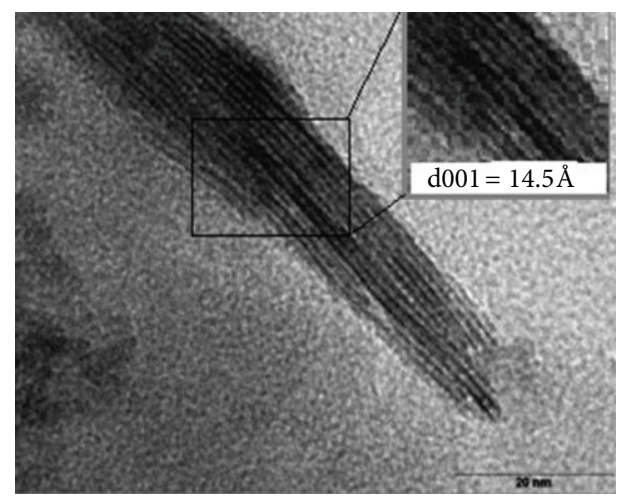

(a)

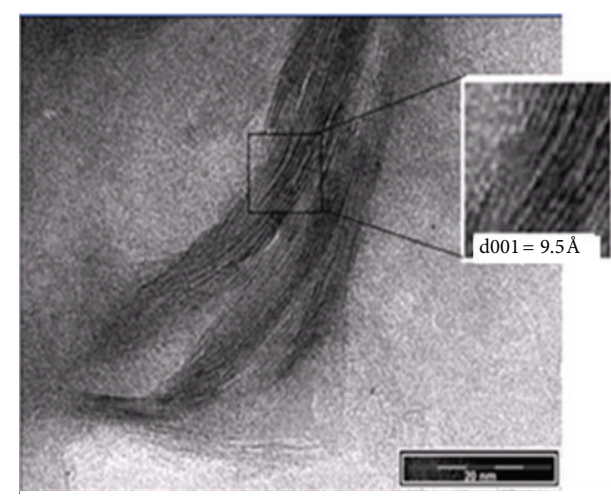

(b)

FIgURE 3: TEM observations of RBC (a) and RGC (b).

TABLE 3: Textural analysis of samples.

\begin{tabular}{lcc}
\hline Parameters & RGC & RBC \\
\hline Real volumic mass $\rho_{s}\left(\mathrm{~g} / \mathrm{cm}^{3}\right)$ & 2.58 & 2.18 \\
Apparent volumic mass $\rho_{p}\left(\mathrm{~g} / \mathrm{cm}^{3}\right)$ & 1.87 & 1.38 \\
Internal porosity $\chi(\%)$ & 27.77 & 36.69 \\
Specific surface $S_{\text {BET }}\left(\mathrm{m}^{2} / \mathrm{g}\right)$ & 36.00 & 56.47 \\
\hline
\end{tabular}

As shown in Table 3, the Specific Surface area $S_{\text {BET }}$ of RBC is $56.47 \mathrm{~m}^{2} / \mathrm{g}$, which is much larger than that of RGC. This confirms the XRD and MET results.

\subsection{Effect of the Physicochemical Parameters on the Retention of OM onto Used Adsorbents}

3.2.1. Effect of Contact Time. The time-dependent behaviour of lead adsorption was studied by varying the contact time between the SOM and adsorbent in the range of 1-120 min. The initial concentration of OM was kept as $491 \mathrm{ppm}$, while the dose of RBC and RGC samples was $1 \mathrm{~g}$. The data showed that the sorption of lead OM on the two studied clay samples was fast and the equilibrium was reached after $90 \mathrm{~min}$ (Figure 4). The adsorption process is fast at the beginning of the reaction due to the adsorption of OM on the surface sites of clay, and then it becomes slow due to the diffusion of OM from the surface sites to the interlayer of the solid $[16,19]$. Therefore, a 90 min contact time was found to be appropriate for maximum adsorption and was used in all subsequent measurements.

3.2.2. The Temperature Effect. To examine the temperature effect on the OM retention, the same conditions were

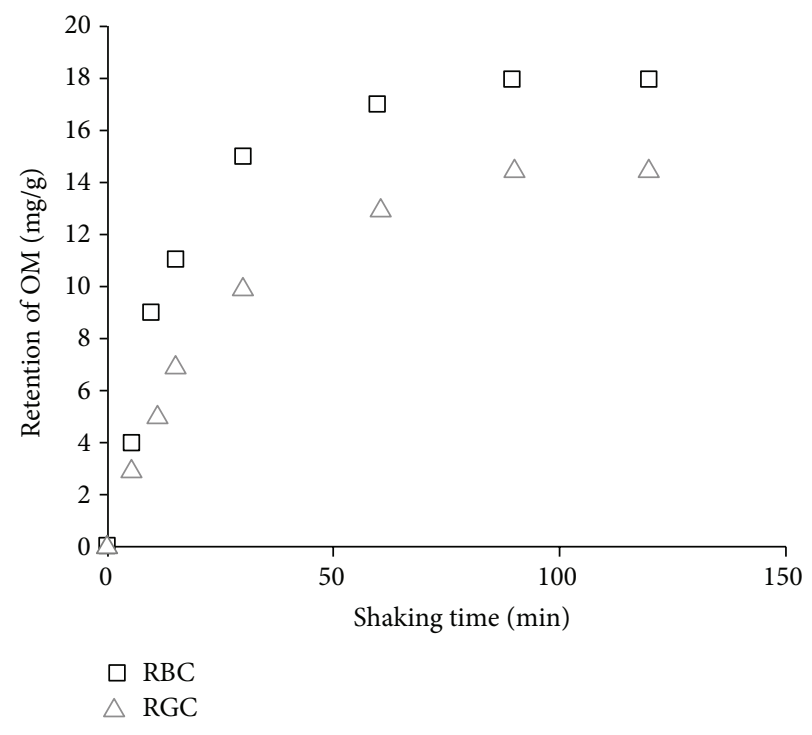

FIGURE 4: Effect of shaking time on retention of OM present in phosphoric acid using (a) RBC and (b) RGC; (Particle size: $63 \mu \mathrm{m}$; $C_{0}=491 \mathrm{ppm} ; S / L=20 \mathrm{~g} / \mathrm{L} ; T: 35^{\circ} \mathrm{C}$ ).

kept while varying the temperature. According to Figure 5, when the temperature increases, the OM adsorption capacity decreases and the $\mathrm{OM}$ retention reaches its maximum at $35^{\circ} \mathrm{C}$; which would be due to an increase in desorption at high temperature [18] confirming that adsorption is an exothermic phenomenon. Figure 5 confirms the fact that adsorption is physical: the adsorption rate is improved when $T^{\circ}$ decrease $[15,16]$. For the three investigated temperatures, equilibrium is reached after $90 \mathrm{~min}$. 


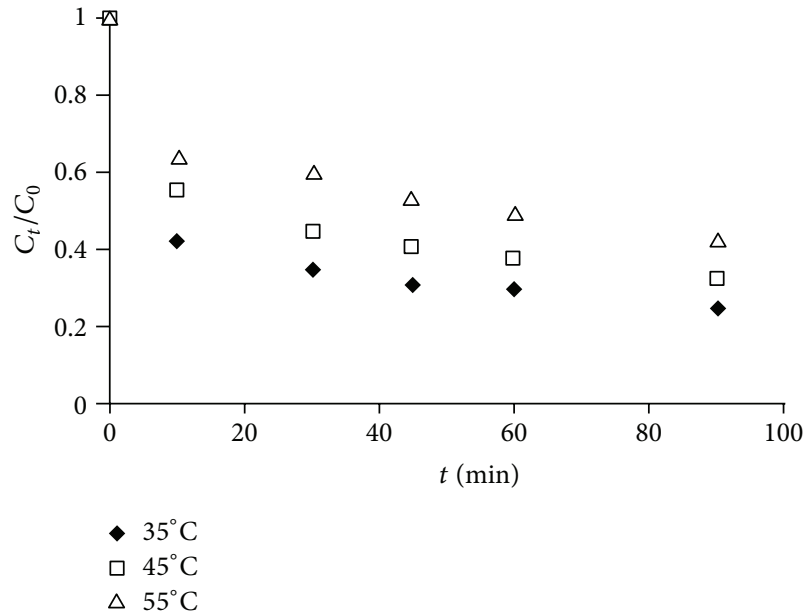

(a)

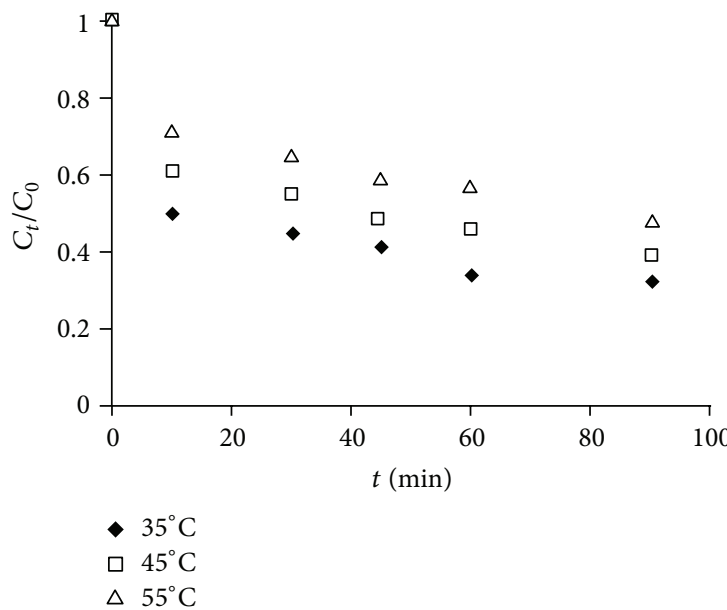

(b)

FIgURE 5: Effect of Temperature on OM retention using: (a) RBC and (b) RGC; (Particle size: $63 \mu \mathrm{m} ; C_{0}=491 \mathrm{ppm} ; \mathrm{S} / \mathrm{L}=20 \mathrm{~g} / \mathrm{L}$ ).

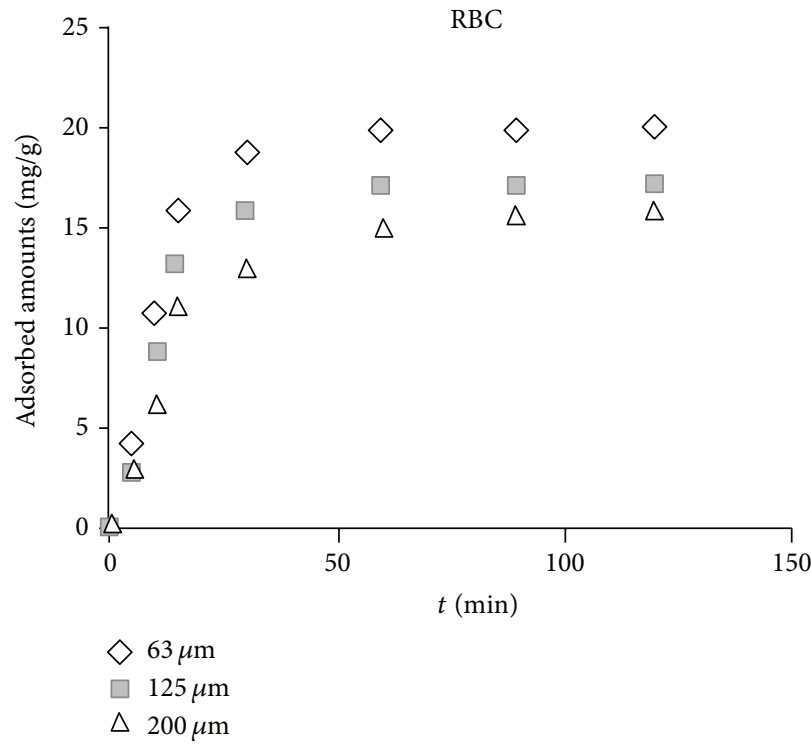

(a)

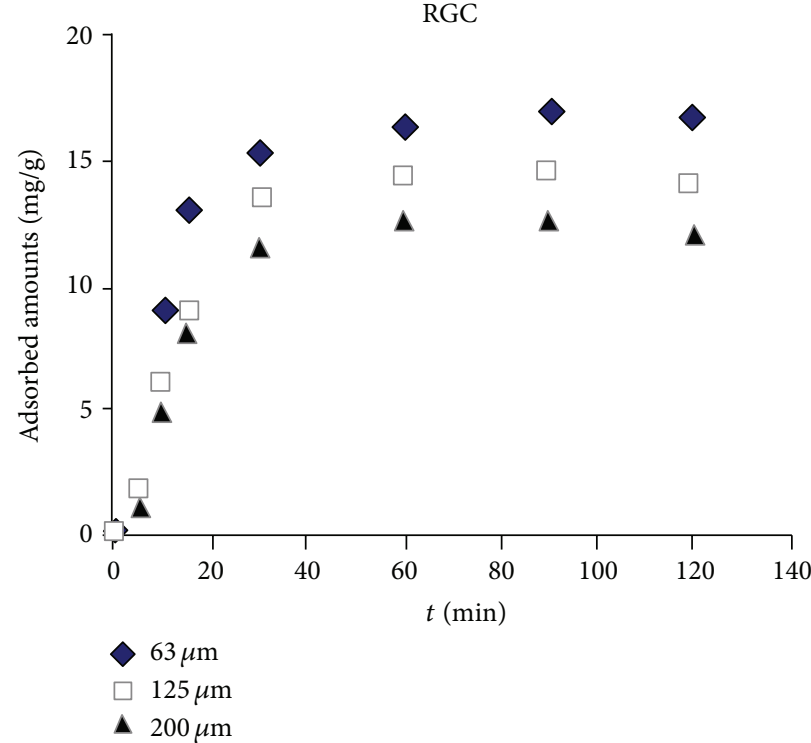

(b)

Figure 6: Effect of particle size on retention of OM using (a) RBC and (b) RGC $\left(C_{0}=491 \mathrm{ppm} ; \mathrm{PS}=63 \mu \mathrm{m} ; \mathrm{S} / \mathrm{L}=20 \mathrm{~g} / \mathrm{L}, T^{\circ}=35^{\circ} \mathrm{C}\right)$.

3.2.3. Effect of Particle Size. Three particle sizes were used: 63, 125 , and $200 \mu \mathrm{m}$. Figure 6 shows that the rate of adsorption slightly improves when the particle size decreases. This is due to the fact that the surface area increases slightly with decreasing particle size.

\subsection{Retention of Organic Matter Contained in Industrial} Phosphoric Acid. In our case, the industrial phosphoric acid presented a high solute concentration in the form of minerals so it has a high ionic strength (Table 1). It was noted that the adsorption depends on ionic strength and may be explained by several mechanisms.

(1) In high ionic strength condition a decrease of molecular volume of humic substance can noticed due to minimization of the electrostatic repulsion between ionized oxygen groups, which facilitates the adsorption.

(2) In high ionic strength condition, a compression of the thickness of the diffuse double layer which surrounds solid and liquid phases when they are in contact, is possible. Such compression helps the clay particles and humic substance molecules to approach each other more closely.

(3) In addition, at higher ionic strength, the solubility of humic substance is lower, a fact that favors the mass transfer of humic substance from the solution phase to the solid phase of clay [19-21]. 
TABLE 4: Isotherm constants of O.M adsorption onto RBC and RGC samples at $35^{\circ} \mathrm{C}$ (particle size: $63 \mu \mathrm{m} ; C_{0}=491 \mathrm{ppm} ; \mathrm{S} / \mathrm{L}=20 \mathrm{~g} / \mathrm{L} ; \mathrm{T}$ : $\left.35^{\circ} \mathrm{C}\right)$

\begin{tabular}{lcccrr}
\hline \multirow{2}{*}{ Adsorbents } & \multicolumn{2}{c}{ Langmuir equation } & \multicolumn{3}{c}{ Freundlich equation } \\
& $q_{m}(\mathrm{mg} / \mathrm{g})$ & $K_{L}(\mathrm{~L} / \mathrm{mg}) 10^{3}$ & $R^{2}$ & $\ln K_{F}$ & $1 / n$ \\
\hline RBC & 17.26 & 3.0 & 0.994 & -31.12 & 13.06 \\
RGC & 15.05 & 3.5 & 0.984 & -42.32 & 14.32 \\
\hline
\end{tabular}

3.4. Adsorption Isotherms Models. To describe the adsorption process of $\mathrm{OM}$ contained in industrial phosphoric acid onto the two considered solid supports (RBC and RGC), two empirical models are tested, which are the Langmuir and the Freundlich isotherms. These two models are generally reliable in modeling the adsorption of inorganic and organic matter in solutions.

The Langmuir and Freundlich models are the simplest and the most commonly used isotherms to represent the adsorption of components from a liquid phase onto a solid phase [22]. The OM adsorption experiment isotherms were carried out at temperature of $35^{\circ} \mathrm{C}$ by varying the time in the ranges previously defined (in chemical solutions). All other parameters were kept constant. The obtained equilibrium adsorption data were fitted on the linearly transformed Langmuir and Freundlich equations.

Langmuir model assumes a monolayer adsorption. The obtained adsorption data were fitted by the linearized Langmuir equation

$$
\frac{C_{e}}{q_{e}}=\frac{1}{q_{m} K_{L}}+\frac{C_{e}}{q_{m}} .
$$

Both $q_{m}$ and $K_{L}$ could be determined from the slope and intercept of the linear plot $C_{e} / q_{e}$ against $C_{e}$, respectively. $C_{e}$ is the equilibrium concentration of OM (milligrams per litre), $q_{e}$ is the adsorbed amount of OM (milligrams per gram), $q_{m}$ (milligrams per gram) is the maximum adsorption capacity, and $K_{L}$ is the Langmuir constant related to the adsorption energy [23].

The parameters derived from the least-square fitting of the isotherms by the linearized Langmuir equation (Figure 7) are given in Table 4.

In Table 4, we brought different values of $K_{L}, R_{2}$ and $q_{m}$ obtained at $35^{\circ} \mathrm{C}$.

The monolayer capacity $\left(q_{m}\right)$ for RBC and RGC was 14 and $18 \mathrm{mg} \cdot \mathrm{g}^{-1}$, respectively.

The main characteristics of the Langmuir isotherm can be also expressed in terms of a dimensionless constant separation factor or equilibrium parameter, $R_{L}$, which was defined as:

$$
R_{L}=\frac{1}{1+K_{L} C_{0}},
$$

where $C_{0}$ is the initial OM concentration. The $R_{L}$ value indicates the shape of the isotherm as follows: favourable adsorption is indicated by $0<R_{L}<1$ while $R_{L}>1, R_{L}=1$, and $R_{L}=0$ describe, respectively, unfavourable, linear, and irreversible adsorption [24]. The $R_{L}$ values calculated for OM initial concentration of $491 \mathrm{ppm}$ were 0.0033 and 0.0028 at

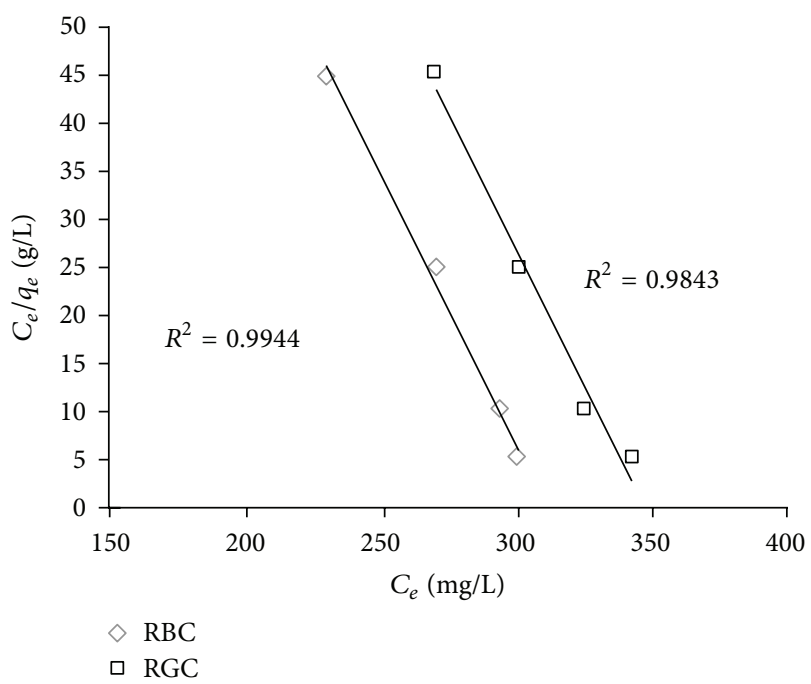

FIGURE 7: Langmuir equilibrium isotherms of OM adsorbed onto $\mathrm{RBC}$ and RGC.

$35^{\circ} \mathrm{C}$ for RGC and RBC, respectively. Hence, the adsorption of OM on RBC and RGC was favourable.

The linearized Freundlich equation was expressed as follows:

$$
\log q_{e}=\log K_{F}+\frac{1}{n} \log C_{e}
$$

where $K_{F}$ and $1 / n$ are constant and considered as indicators of adsorption intensity. The derived parameters from leastsquare fittings of the Langmuir and Freundlich equations are given, respectively, in Table 4 . Freundlich constants, $K_{F}$ and $1 / n$, were determined from the linear plot of $\log q_{e}$ versus $\log C_{e}$ (Figure 8).

The correlation coefficients $\left(R^{2}\right)$ given in Table 4 show that the Langmuir equation gives a fairly good fit to the sorption isotherm.

The used bentonite clay, being a polar adsorbent, preferably adsorbs polar molecules [25]. The Langmuir isotherm was characterized by a rise in the adsorption capacity. This can be explained by the penetration of the OM in the macroand micropores of the adsorbent, forming new adsorption surfaces or by the formation of multilayers as a result of the interactions between the OM and adsorbate [16].

Results in Table 3 show that the maximum adsorption capacity values, $Q_{0}$, are $17 \mathrm{mg} / \mathrm{g}$ for $\mathrm{RBC}$ and 15 for RGC at a temperature of $35^{\circ} \mathrm{C}$ and optimum conditions. The observed maximum sorption capacity of RGC for OM removal remained slightly lower compared to maximum 
TABLE 5: Thermodynamic parameters.

\begin{tabular}{llccccc}
\hline & & $308 \mathrm{~K}$ & $318 \mathrm{~K}$ & $328 \mathrm{~K}$ & $-\Delta H^{\circ}\left(\mathrm{KJ} \mathrm{mol}^{-1}\right)$ & $-\Delta S^{\circ}\left(\mathrm{KJ} \mathrm{mol}^{-1} \mathrm{~K}\right)$ \\
\hline RBC & $-\Delta G^{\circ}$ & 11.41 & 11.63 & 11.72 & 13.26 & 0.083 \\
RGC & $-\Delta G^{\circ}$ & 11.26 & 11.41 & 11.47 & 15.4 & 0.081 \\
\hline
\end{tabular}

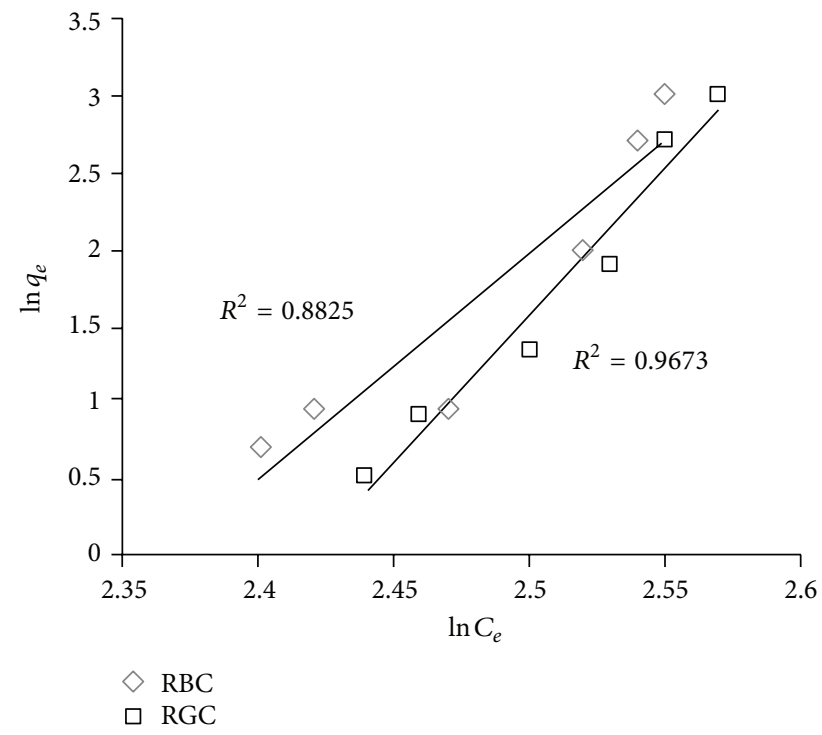

FIGURE 8: Logarithmic plot of Freundlich equilibrium isotherms of OM absorbed onto RBC and RGC.

sorption capacities of RBC which confirm the results found previously.

3.5. Thermodynamic Parameters of Adsorption. To evaluate the nature of adsorption of OM contained in industrial phosphoric acid onto raw studied clays, the removal process was analysed in terms of thermodynamic behaviour. To achieve this goal, three thermodynamic parameters, including free energy $\left(\Delta G^{\circ}\right)$, enthalpy $\left(\Delta H^{\circ}\right)$ and entropy change $\left(\Delta S^{\circ}\right)$, and distribution coefficient $K_{d}$ [26], were determined by the following equation:

$$
\begin{aligned}
\Delta G^{\circ} & =-R T \ln K_{L}, \\
\ln K_{L} & =\frac{\Delta S^{\circ}}{R}-\frac{\Delta H^{\circ}}{R T},
\end{aligned}
$$

where $T$ (kelvin) is the temperature and $R\left(8.314 \mathrm{~J} \mathrm{~mol}^{-1} \mathrm{~K}^{-1}\right)$ is the universal gas constant. The values of $\Delta H^{\circ}$ and $\Delta S^{\circ}$ were determined from the slopes and intercepts of the plots of $\ln K_{L}$ versus $1 / T$ [27] (Figure 9). The calculated thermodynamic parameters indicated that $\Delta H^{\circ}$ values were -13.26 and $-15.4 \mathrm{~kJ} \mathrm{~mol}^{-1}$ for $\mathrm{RBC}$ and RGC, respectively (Table 5).

According to Table 4, the negative values obtained for $\Delta G^{\circ}$ indicated the spontaneous nature of adsorption (Table 5). The data of $\Delta H^{\circ}$ and $\Delta S^{\circ}$ values of OM adsorption on the studied samples indicated that adsorption phenomenon is exothermic $[28,29]$.

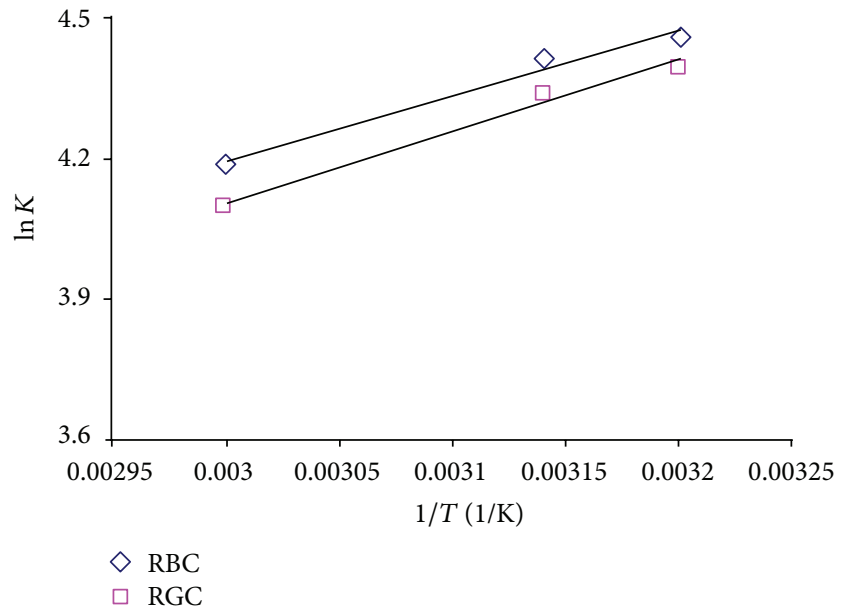

FIgURE 9: Relationship between $1 / T$ and $\ln K_{d}$ for the adsorption of OM on the studied samples $\left(V_{\text {Speed }}=200 \mathrm{r} / \mathrm{min} ; C_{0}=491 \mathrm{ppm}\right.$; $\left.S / L=20 \mathrm{~g} / \mathrm{L} ; T: 35^{\circ} \mathrm{C}\right)$.

3.6. Comparison of Capacity Adsorption with Activated Carbon. Figure 10 shows that the adsorption capacity of activated carbon towards OM was better than the two other adsorbents (RBC and RGC) due to its high specific surface area, total pore volume, and internal structure $\left(1000 \mathrm{~m}^{2} \mathrm{~g}^{-1}\right)$. The clay can undergo further treatment (by pillaring another inorganic or organic compound) to change its internal structure while following its internal texture so that it approximates texture of coal to have a good adsorption capacity.

\section{Conclusions}

From the above study, it may be concluded that the adsorption characteristic has been examined with the variations in the parameters of contact time, agitation speed, and temperature. The most efficient $\mathrm{OM}$ adsorption is that obtained under the following optimal conditions: temperature $\left(35^{\circ} \mathrm{C}\right)$; solid/liquid ratio $(r=20 \mathrm{~g} / \mathrm{L})$; agitation speed $(V=400 \mathrm{rpm})$; shaking time: $90 \mathrm{~min}$. The removal efficiency of two different clay samples illite and smectite was found to be 14 and $18 \mathrm{mg} / \mathrm{g}$, respectively, at optimum conditions. The equilibrium data could be described by the Langmuir and Freundlich isotherm equations, and the Langmuir model appears better to represent the adsorption process than the Freundlich model. In this work, the $\Delta H^{\circ}$ and $\Delta S^{\circ}$ values of OM adsorption on the studied samples indicated that adsorption phenomenon is exothermic. The negative value of $\Delta G^{\circ}$ confirms the feasibility of the retention process as well as its spontaneity. The comparison between OM adsorption capacities of used raw clay materials showed the efficiency of 


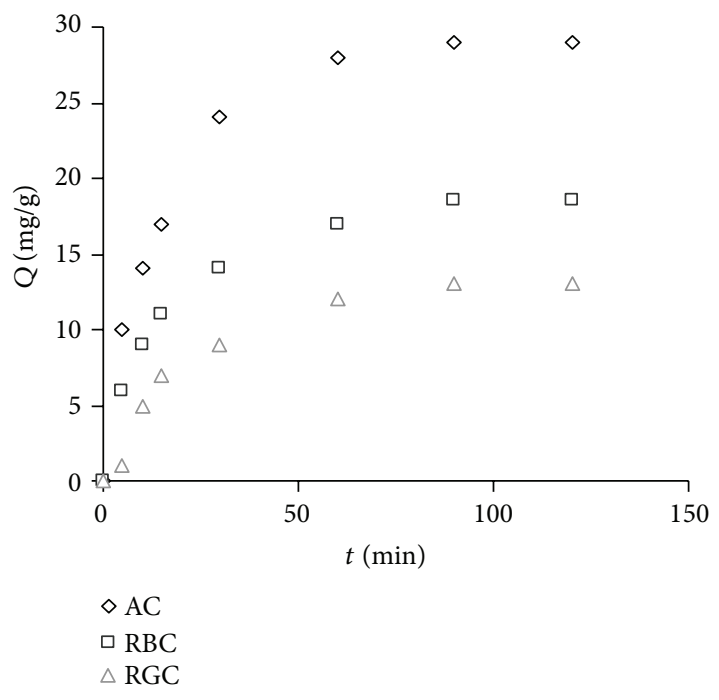

FIgURE 10: Evolution of the retention rate of OM by different adsorbents $\left(T=35^{\circ} \mathrm{C} ; V_{\text {Speed }}=200 \mathrm{r} / \mathrm{min} ; C_{0}(\mathrm{O} . \mathrm{M})=491 \mathrm{ppm}\right.$; amount clay: $10 \mathrm{~g} \mathrm{~L}^{-1}$ ).

bentonite clay in purification of industrial phosphoric acid in significant amount. The clay can undergo further treatment (by pillaring another inorganic or organic compound) to change its internal structure while following its internal texture so that it approximates texture of coal to have a good adsorption capacity.

\section{Acknowledgments}

Thanks are extended to Mr. Brahim Ben Letaief, Technician in Laboratory of Atomic Absorption, ENIS-Sfax, for facilitating the analysis of samples using atomic absorption spectrometer (AAS). The authors extend their thanks to Mr. Nidhal Baccar, Technician in University of Sfax-Tunisia for his help and Miss Amina Zineeddine, Technician in industrial chemical laboratory (II), ENIS-Sfax, for RX analysis.

\section{References}

[1] A. A. Hanna and A. F. Ali, "Removal of organic matter from crude wet-process phosphoric acid," Journal of Chemical Technology and Biotechnology, vol. 55, no. 3, pp. 205-208, 1992.

[2] M. Baudu, G. Guibaud, D. Raveau, and P. Lafrance, "Prevision de l'adsorption de molecules organiques en solution aqueuse en fonctions de quelques caracteristiques physicochimiques de charbons actifs," Water Quality Research Journal, vol. 36, no. 4, pp. 631-657, 2001.

[3] A. Hannachi, D. Habaili, C. Chtara, and A. Ratel, "Purification of wet process phosphoric acid by solvent extraction with TBP and MIBK mixtures," Separation and Purification Technology, vol. 55, no. 2, pp. 212-216, 2007.

[4] A. Mellah, S. Chegrouche, and L. Setti, "Prétraitement de l'acide phosphorique industriel par les terres filtrantes algériennes," International Journal of Mineral Processing, vol. 41, no. 3-4, pp. 295-303, 1994.
[5] A. Mellah, A. Silem, R. Kada, and A. Boualia, "Qualitative and quantitative analysis of organic matter contained in industrial phosphoric acid," Canadian Journal of Applied Spectroscopy, vol. 36, no. 2, pp. 94-105, 1991.

[6] A. Silem, A. Boualia, A. Mellah, and R. Kada, "Adsorption of organic matter from a wet phosphoric acid using activated carbon: batch-contact time study and linear driving force models," Canadian Journal of Chemical Engineering, vol. 70, no. 2, pp. 491-496, 1992.

[7] A. Mellah and D. Benachour, "Adsorption of heavy metals from industrial phosphoric acid by Algerian activated bentonlte," Annales de Chimie, vol. 32, no. 5, pp. 487-504, 2007.

[8] N. S. Awwad, A. A. M. Daifullah, and S. A. El-Reefy, "Purification of wet phosphoric acid from ferric ions using modified rice husk," Chemical Engineering Journal, vol. 81, no. 5, pp. 7683, 2000.

[9] A. Bendada, A. H. Meniai, and L. M. Bencheik, "Modeling of phosphoric acid purification by liquide-liquide extraction," Chemical Engineering and Technology, vol. 24, pp. 1273-1280, 2001.

[10] G. Bouc, J. C. Henghebaert, M. Chaabouni, and H. F. Ayedi, "Procédé de séparation d'impuretés à base de magnésium et éventuellement d'aluminium et de fluor d'un acide phosphorique préparé par voie humide," Patent F 84-14734, 1984.

[11] G. Akçay, M. Akçay, and K. Yurdakoç, "The characterization of prepared organomontmorillonite (DEDMAM) and sorption of phenoxyalkanoic acid herbicides from aqueous solution," Journal of Colloid and Interface Science, vol. 296, no. 2, pp. 428433, 2006.

[12] A. A. M. Daifullah, B. S. Girgis, and H. M. H. Gad, "A study of the factors affecting the removal of humic acid by activated carbon prepared from biomass material," Colloids and Surfaces $A$, vol. 235, no. 1-3, pp. 1-10, 2004.

[13] M. Eloussaief, W. Hamza, N. Kallel, and M. Benzina, "Wastewaters decontamination: mechanisms of $\mathrm{PB}(\mathrm{II}), \mathrm{ZN}(\mathrm{II})$, and $\mathrm{CD}$ (II) competitive adsorption on tunisian smectite in single and multi-solute systems," Environmental Progress and Sustainable Energy, vol. 27, no. 4, 2012.

[14] S. Najar, A. ben Fraj, A. Zammouri, A. M. ouederni, and A. Ratel, "removal of OM from IPA by AC prepared from olives stones," Journal of Materials Science and Technology, vol. 10, pp. 73-81, 2002.

[15] A. Boualia, A. Mellah, T. T. Aissaoui, K. Menacer, and A. Silem, "Adsorption of organic matter contained in industrial H3PO4 onto bentonite: batch-contact time and kinetic study," Applied Clay Science, vol. 7, no. 6, pp. 431-445, 1993.

[16] B. Khoualdia, M. Loungou, and E. Elaloui, "Adsorption of organic matter from industrial phosphoric acid (H3PO4) onto activated bentonite," Arabian Journal of Chemistry. In press.

[17] G. Brown, The X-Ray Identification and Crystal Structures of Clay Minerals, vol. 544, Mineralogical Society, 1961.

[18] M. Akçay, "Characterization and adsorption properties of tetrabutylammonium montmorillonite (TBAM) clay: thermodynamic and kinetic calculations," Journal of Colloid and Interface Science, vol. 296, no. 1, pp. 16-21, 2006.

[19] D. Doulia, C. Leodopoulos, K. Gimouhopoulos, and F. Rigas, "Adsorption of humic acid on acid-activated Greek bentonite," Journal of Colloid and Interface Science, vol. 340, no. 2, pp. 131$141,2009$.

[20] Y. Seki and K. Yurdakoc, "Adsorption of promethane hydrochloride with KSF," Monmorillonite, vol. 12, pp. 89-897, 2006. 
[21] J. P. Chen and S. Wu, "Simultaneous adsorption of copper ions and humic acid onto an activated carbon," Journal of Colloid and Interface Science, vol. 280, no. 2, pp. 334-342, 2004.

[22] E. S. Abechi, C. E. Gimba, A. Uzairu, and J. A. Kagbu, "Kinetics of adsorption of methylene blue onto activated carbon prepared from palm kernel shell," Archives of Applied Science Research, vol. 3, no. 1, pp. 154-164, 2011.

[23] K. S. Tong, A. Azraa, and M. J. Noordin, "Isotherms and kinetics studies on the removal of methylene blue from aqueous solution by Gambir," International Journal of Environmental Science and Development, vol. 3, no. 3, pp. 232-236, 2012.

[24] I. Christl and R. Kretzschmar, "Interaction of copper and fulvic acid at the hematite-water interface," Geochimica et Cosmochimica Acta, vol. 65, no. 20, pp. 3435-3442, 2001.

[25] C. H. Giles, D. Smith, and A. Huitson, "A general treatment and classification of the solute adsorption isotherm. I. Theoretical," Journal of Colloid And Interface Science, vol. 47, no. 3, pp. 755765,1974 .

[26] M. Akçay, "Characterization and determination of the thermodynamic and kinetic properties of $\mathrm{p}-\mathrm{CP}$ adsorption onto organophilic bentonite from aqueous solution," Journal of Colloid and Interface Science, vol. 280, no. 2, pp. 299-304, 2004.

[27] G. Moussavi, S. Talebi, M. Farrokhi, and R. M. Sabouti, "The investigation of mechanism, kinetic and isotherm of ammonia and humic acid co-adsorption onto natural zeolite," Chemical Engineering Journal, vol. 171, no. 3, pp. 1159-1169, 2011.

[28] N. Yilmez and S. Yaper, "Adsorption properties of tetradecyl and hexadecyltrimethyl ammonium bentonites," Applied Clay Science, vol. 27, pp. 223-228, 2004.

[29] P. X. Wu, Z. W. Liao, H. F. Zhang, and J. G. Guo, "Adsorption of phenol on inorganic-organic pillared montmorillonite in polluted water," Environment International, vol. 26, no. 5-6, pp. 401-407, 2001. 

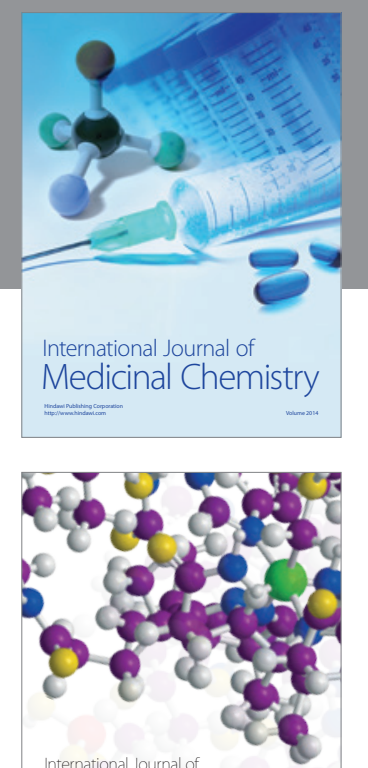

\section{Carbohydrate} Chemistry

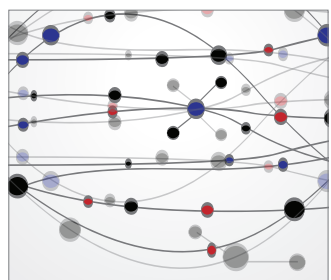

The Scientific World Journal
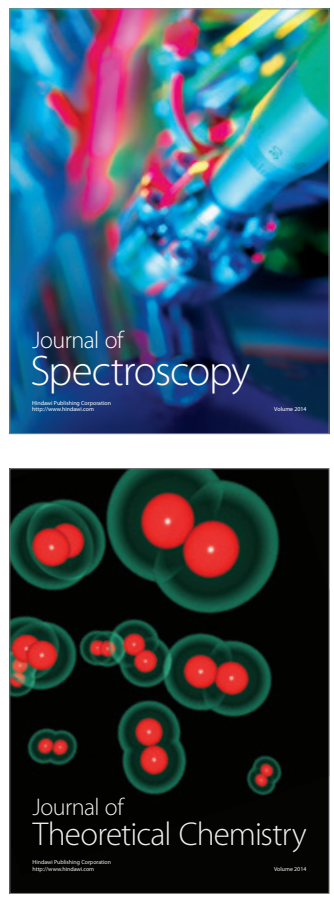
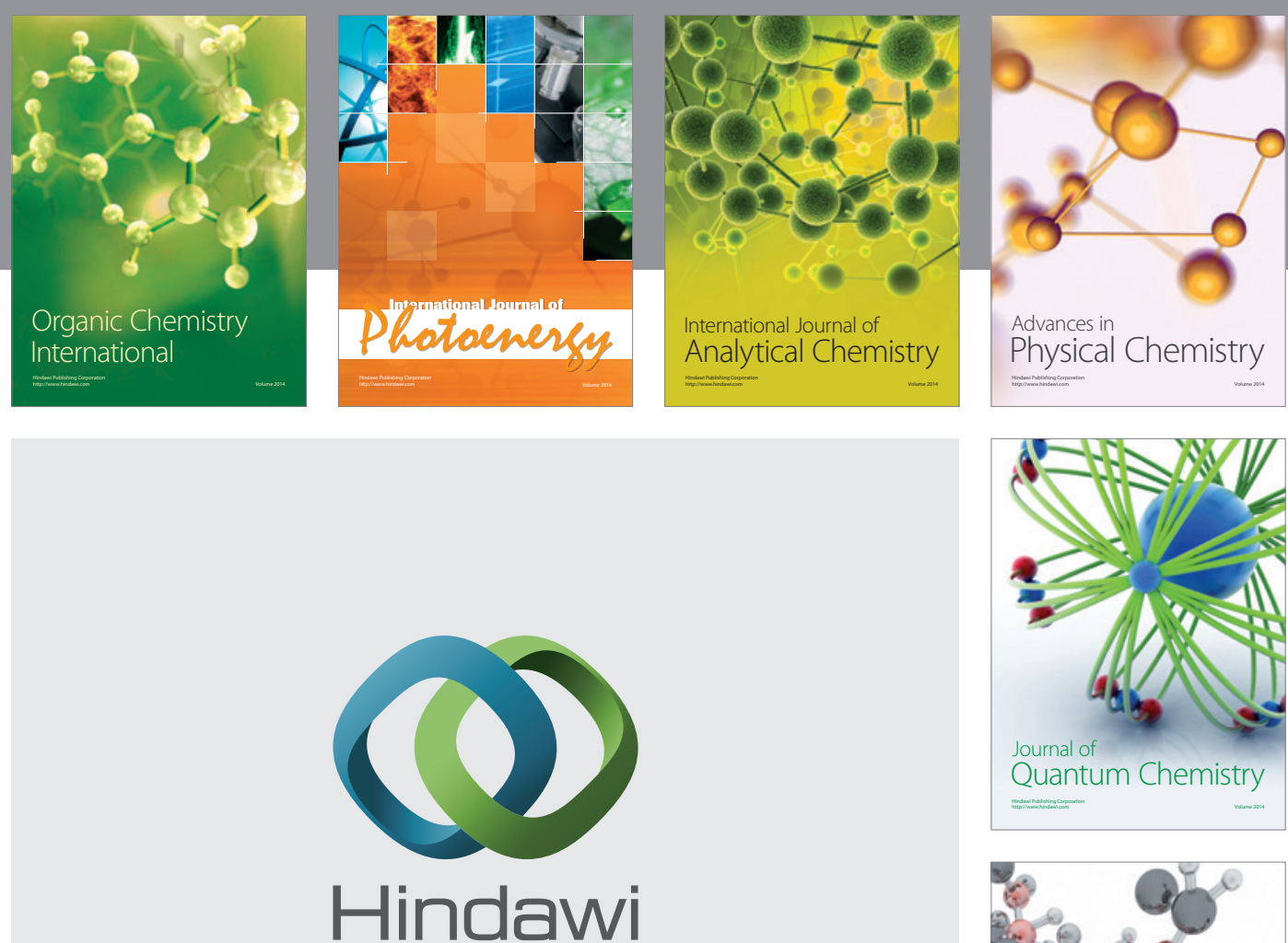

Submit your manuscripts at

http://www.hindawi.com

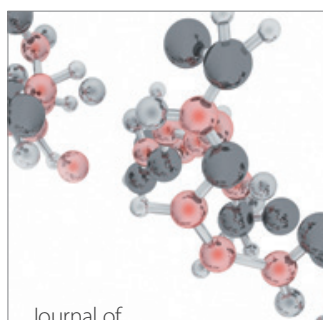

Analytical Methods

in Chemistry

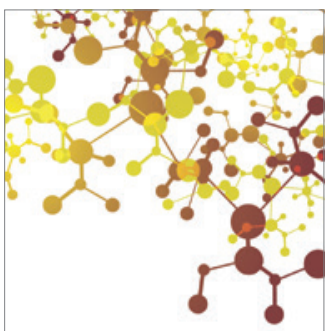

Journal of

Applied Chemistry

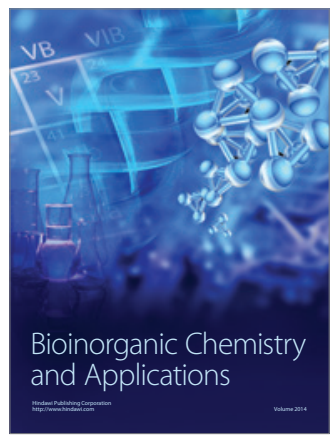

Inorganic Chemistry
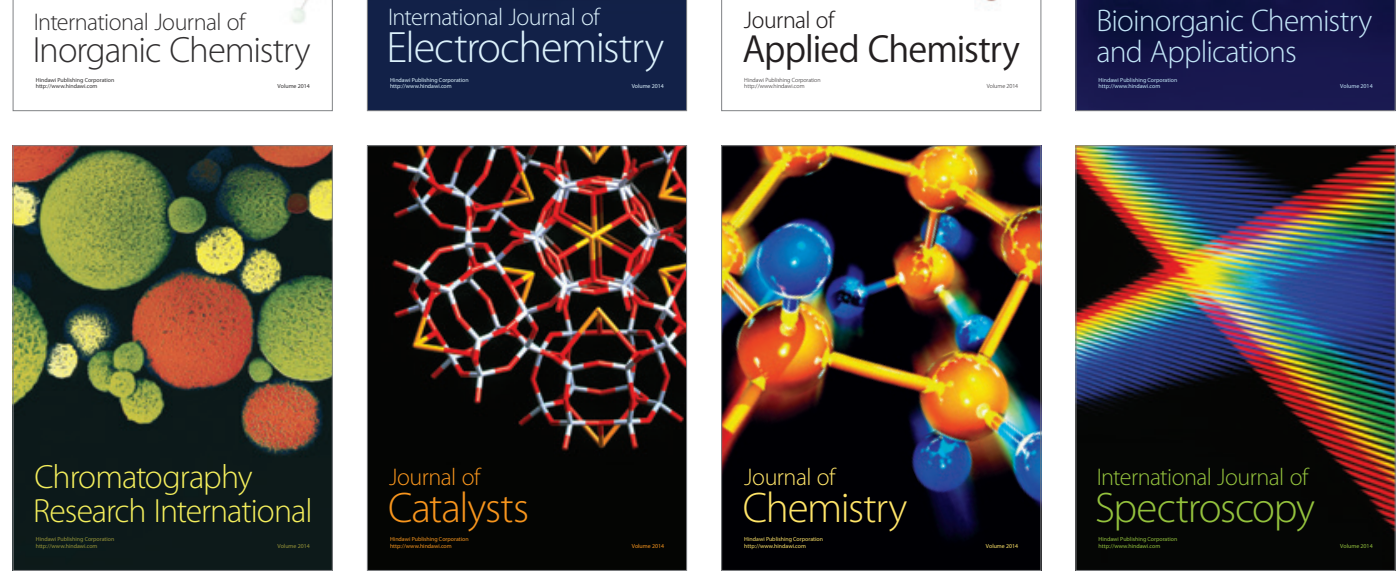